\title{
Opinion
}

\section{Tort-Law based Environmental Litigation: a Victory or a Warning?}

"The Appeal Court confirms the judgment of the The Hague Tribunal of 24 June 2015." With these words on 9 October 2018 - the day before sustainability day the The Hague Appeal Court closed the second, and probably not last, chapter in the renown Urgenda case (ECLI:NL:GHDHA:2018:2591). The Dutch State must reduce its greenhouse gas emissions to a greater extent than envisaged under its current plans.

It does not bear further explanation that this judgment was welcomed as a success by the Urgenda association, other environmental associations, environmentalists and concerned citizens alike. The first commentaries of Dutch scholars have already appeared on national newspapers and internet sites, with commentaries in legal journals following soon. Lucas Bergkamp, Marcel Crok, Jaap Hanekamp \& Roel Pieterma, and Ludwig Krämer have been entrusted with the task to open an in depth discussion on this judgment in the next volume of this journal.

Acordingly, I would like to make immediately clear that I do not want to judge the Urgenda ruling from a substantive perspective. As for most land mark cases, it can surely be both praised and criticized. In this opinion, I want to underline a personal concern that I have with the use of tort law to protect the environment which emerges when we place the Urgenda case in a broader perspective.

The words of Marleen van Rijswick during her keynote at the $6^{\text {th }}$ EELF Conference in Como, Italy (available at eelf.info), keep echoing in my mind. She rightly warned the audience that the Urgenda case is actually a symptom of problem, not a solution. It highlights the failure of the Dutch State to take climate change seriously. After hearing these words, my mind immediately made

(C) LORENZO SQUINTANI, 2019 | DOI 10.1163/18760104-01503003

This is an open access article distributed under the terms of the prevailing CC-BY-NC license at the time of publication. 
a link to a proposition from the insightful book of the Italian civil law lawyer Natalino Irti, Codice civile e società politica (Laterza 2007, chapter 1), indicating, in essence, that any time the Constitutional charter is under pressure the Civil Code rises as carrier of the values of unity and stability of civil society. My Italian colleagues will hopefully excuse me for interpreting these words as meaning that civil law steps-in when public law fails to fulfil its tasks, which is exactly what is happening in the Netherlands in the context of climate change, as shown by the Urgenda case.

This safety-net function of civil law may sound reassuring to many, but the ongoing deployment of this safety-net in the Netherlands makes me wonder whether it is suitable for the task. Because if it is not, it would generate a false sense of assurance, which could slow down, rather than spur, environmental protection.

A quick excursion in the field of air quality law is necessary to better understand the potential threat embedded in the tort-law route to environmental protection. While lawyers from all over the world are familiar with the Urgenda case, only few (Dutch) environmental lawyers are familiar with its troublesome progeny in the field of air quality law. Inspired by the Urgenda case, non-governmental organizations and individual citizens in the Netherlands started tort-law based proceedings against the Netherlands to combat air pollution, which in the Netherlands is responsible for the premature death of thousands of people each year (European Environment Agency (EEA), Air quality in Europe, 2018). As a matter of facts, at several key locations in the Netherlands, the national air quality standards, of clear EU derivation, are not complied with by the Netherlands. Dutch plans to redress the exceedances show that the situation will not be solved in the short term. One environmental organization, Milieudefensie, and other applicants started an Urgenda-like action to force the Dutch State to do more. More precisely, two actions were started, a summary proceedings (first instance ECLI:NL:RBDHA:2017:10171; appeal ECLI:NL:G HDHA:2018:1128) and a regular one (first instance ECLI:NL:RBD HA:2017:15380). The judgment in the regular procedure is the most interesting one for my reflection.

On 27 December 2017, the The Hague Tribunal, as in the Urgenda case (but with a different composition of the chamber), rejected the claim of the applicants. The tribunal reached an opposite conclusion to the one seen in the first instance Urgenda judgment, now confirmed in appeal.

Why? What was different in the pleadings of Milieudefensie, in comparison to those of Urgenda, that could justify the difference in outcomes? What was the difference in the reasoning of the court in the air quality case that could 
explain the difference in the outcome in comparison to the climate law case? Is there an intrinsic difference between climate change law and air quality law that explains the two different outcomes?

Clearly, only an in depth analysis of both cases and their respective normative frameworks can answer these questions satisfactorily. My first glance reading of the judgments and the relative legal frameworks only spotted a marked difference in the manner in which the courts looked at key elements of the tort-law action, namely the concepts of damage, the existence of a causal link and the burden of proof.

To my great dissatisfaction, I cannot understand why these concepts where viewed differently in these two cases. This also means that I do not know how the case-law will develop. The Netherlands will probably go in cassation in the Urgenda case; Milieudefensie filed an appeal in the air quality case. Will the Dutch Supreme Court change the outcome of the Urgenda case by following a reasoning more in line with the one of the The Hague Tribunal in the air quality case? Will the The Hague Appeal Court change the outcome of the first instance judgment by following the reasoning adopted in the Urgenda (appeal) case? Will the difference in reasoning be maintained, presumably entailing that the difference in outcomes will also be maintained? Will the eventual differences in reasoning and outcomes be explained? And more generally, what would happen in other environmental fields, as water law in which the Netherlands is miserably failing to fulfil the Water Framework Directive objectives (EEA, European waters - Assessment of status and pressures 2018), were tortlaw actions started to spur environmental protection?

I sincerely do not know what to expect, and surely I am not the only one. There is too much uncertainty at the moment to predict what the course of the case law would be. This means that the extent and the functioning of tort law as a safety net for public law shortcomings in environmental protection in the Netherlands is far from clear.

At the moment, beginning a tort-law action to protect the environment is similar to taking a gamble. This uncertainty can hardly have a positive effect for civil society in general, and environmental protection in particular. Arguably, the only party that benefits from this uncertainty is the State. The State could use this uncertainty to avoid reforming public law, both from a substantive and a procedural perspective. It can decide to wait until a civil court rules on whatever shortcoming as regards the achievement of environmental quality standards before considering developing and implementing effective policies. In fact, this hypothesis is not far from what is occurring in the field of air quality law. 
In light of the above, I warn the readers of this journal not to cheer blindly to the developments originating in the Netherlands. The Urgenda case is only a piece of the puzzle. We should reflect upon the question of whether tort-law based environmental litigation should not be seen as a dire warning, before embracing it as a victory.

Lorenzo Squintani 